\title{
Seksualitas dan Perkembangan Gamet Sponge Laut Aaptos aaptos Schmidt
}

\author{
Abdul Haris ${ }^{\text {*) }}$, Dedi Soedharma ${ }^{2)}$, Neviaty P. Zamani ${ }^{2)}$, John I. Pariwono ${ }^{2)}$, dan Rachmaniar ${ }^{3}$ \\ ${ }^{1)}$ Fakultas Ilmu Kelautan dan Perikanan Universitas Hasanuddin, Makassar 90245 \\ ${ }^{2)}$ Fakultas Perikanan dan Ilmu Kelautan, Institut Pertanian Bogor, Bogor 16680 \\ ${ }^{3)}$ Pusat Penelitian Oseanologi ( $\left.\mathrm{P}_{2} \mathrm{O}\right)$-LIPI, Jakarta 50263 \\ Diterima 23-06 2010 Disetujui 02-11-2012
}

\begin{abstract}
This research was aimed to know the characteristics of gamet development of marine sponge Aaptos aaptos living in tropical waters of Barrang Lompo Island, Spermonde Archipelago, South Sulawesi. In order to know gamet development, it was conducted three periods of sample collection at each moon phase. After sample collection, the specimen were put into tissue cassette and then were removed to fixative solution of FAACC (for $100 \mathrm{~mL}=10 \mathrm{~mL}$ formaldehyde solution of 37-40\%: $5 \mathrm{~mL}$ glacial acetic acid: $1.3 \mathrm{~g}$ calcium chloride dihydrate: $85 \mathrm{~mL}$ destilate water) for \pm 48 hours, and then were removed to $70 \%$ alcohol for temporary storage before doing histological preparation following standard procedure. Sexuality of marine sponge Aaptos aaptos living in Barrang Lompo Island is gonochoric. Spermatocyt developed in spermatic cyst, while oocyt developed in the mesohyl. Stage of male gamet development was divided into four phases i.e. spermatocyt I phase, spermatocyt II phase, spermatocyt III phase, and spermatocyt IV (spermatid) phase, similarly, female gamet development was divided into four phases i.e. oocyt I phase, oocyt II phase, oocyt III, oocyt IV phase. Each phase of gamet development had specific characterstics different from among each others.
\end{abstract}

Keyword: Aaptos aaptos, barrang lompo island, gamet, sponge

\begin{abstract}
ABSTRAK
Penelitian ini bertujuan untuk mengetahui karakteristik perkembangan gamet spons laut Aaptos aaptos yang hidup di perairan tropis Pulau Barang Lompo, Kepulauan Spermonde, Sulawesi Selatan. Untuk mengetahui perkembangan gamet dilakukan tiga periode pengambilan sampel pada setiap fase bulan. Setelah pengambilan sampel, spesimen dimasukkan ke dalam tissue cassette dan kemudian dipindahkan ke dalam larutan fiksatif FAACC (untuk $100 \mathrm{~mL}=10 \mathrm{~mL}$ larutan formaldehida 37-40\%: $5 \mathrm{~mL}$ asam asetat glasial: 1,3 g kalsium klorida dihidrat: $85 \mathrm{~mL}$ akuades) selama \pm 48 jam, dan kemudian dipindahkan ke alkohol $70 \%$ untuk penyimpanan sementara sebelum pembuatan preparat histologinya. Pembuatan preparat histologi mengikuti prosedur standar. Seksualitas spons laut Aaptos aaptos yang hidup di Pulau Barrang Lompo adalah gonokhorik. Spermatosit berkembang di dalam spermatic cyst, sementara oosit berkembang di dalam mesohyl. Tahap perkembangan gamet jantan dibagi menjadi empat tahap yaitu Spermatosit I, Spermatosit II, Spermatosit III, dan Spermatosit IV (spermatid). Begitu Juga perkembangan gamet betina dibagi menjadi empat tahap, yaitu oosit I, oosit II, oosit III, dan oosit IV. Setiap tahap perkembangan gamet baik jantan maupun betina memiliki karakteristik spesifik yang berbeda antara satu sama lain.
\end{abstract}

Kata Kunci: Aaptos aaptos, gamete, sponge, pulau barrang lompo

\section{PENDAHULUAN}

Reproduksi seksual pada sponge memperlihatkan ragam yang sangat besar, tetapi kebanyakan terungkap pada daerah subtropis, dan hanya sebagian kecil yang terungkap pada daerah tropis. Sponge Aaptos aaptos adalah salah satu

*Telp: +62811444812

Email:haris_pagala@yahoo.co.id sponge yang bernilai ekonomis penting (mengandung senyawa antitumor, Aaptamin), yang informasi reproduksi seksualnya masih relatif sedikit yang terungkap. Informasi reproduksi seksual sponge ini hanya diungkapkan oleh Sara (1992), yang menentukan seksualitasnya (gonokhorik) dan cara reproduksinya (ovipar) di Italia. Informasi reproduksi 
seksualnya yang lain diungkapkan juga oleh Ayling (1980), yang menentukan periode reproduksinya (pendek) dan menghasilkan sperma dan oosit secara bersamaan di Selandia Baru.

Seperti pada karang dan hewan avertebrata laut lainnya, sponge juga tidak memiliki ciri seksual sekunder yang dapat digunakan untuk menentukan jenis seksualitasnya. Oleh karena itu, satu-satunya cara yang dapat dilakukan untuk pengamatan tersebut adalah pengamatan histologik pada jaringannya.

Seksualitas pada sponge dapat dikelompokkan atas dua, yaitu: 1) Hermaprodit, yaitu jenis sponge yang menghasilkan baik gamet jantan atau betina selama hidupnya, tetapi menghasilkan telur dan sperma dalam waktu yang berbeda; (2) Gonokhorik, yaitu jenis sponge yang memproduksi hanya gamet jantan atau betina saja selama hidupnya. (Reseck 1988; Kozloff 1990; Ruppert \& Barnes 1991; Amir \& Budiyanto 1996), tetapi pada umumnya seksualitasnya adalah hermaprodit, dan menghasilkan sperma dan oosit pada waktu yang berbeda (Kozzlof 1992; Ruppert \& Barnes 1991; Brusca \& Brusca 1990).

Semua aspek-aspek yang mengatur reproduksi pada sponge kurang banyak diketahui (Bergquist 1978). Suhu diasumsikan sebagai faktor lingkungan utama yang mengatur reproduksi sponge pada daerah beriklim empat, di mana perubahan musiman besar terjadi. Peningkatan suhu umumnya yang terima sebagai suatu faktor lingkungan utama yang mengatur awal aktivitas reproduksi pada sponge di daerah yang perubahan musimnya besar (Sara 1992; Fromont 1994). Korelasi yang kuat antara suhu air laut dan gametogenesis juga telah dilaporkan dalam berbagai penelitian, peningkatan suhu dapat menginduksi produksi gamet dalam banyak kasus (Ereskovsky \& Gonobobleva 2000; Mercurio et al. 2007). Di British Honduras gametogenesis umumnya terjadi antara Maret dan April, di Bahama antara April dan Juni, dan di Cedar Keys (Florida) antara Juni dan Juli. Puncak reproduksi di tiga lokasi tersebut berhubungan dengan suhu air pada $29^{\circ} \mathrm{C}$. Di British Honduras dan Bahama beberapa spesimen ditemukan reproduktif sepanjang tahun, di Cedar Keys reproduksi terhenti pada musim dingin dengan suhu yang turun secara drastis, reproduksi hanya terjadi antara April dan Oktober. Hubungan antara kisaran suhu dan reproduksi ditemukan pada Haliclona loosanoffi di lokasi yang berbeda di Pantai Amerika Utara. Reproduksi terjadi pada kisaran suhu antara $20^{\circ} \mathrm{C}$ dan $27^{\circ} \mathrm{C}$, sedangkan yang diinisiasi penurunan suhu jumlahnya terbatas, seperti sponge jenis Halisarca dujardini, Desmacidon fructicosum, Tethya crypta, dan Aplysina gigantea (Fromont 1999). Di Laut Mediterrania, sponge Axinella damicornis memiliki periode gametogenesis yang panjang, yaitu 7-8 bulan. Spermatosit dan oosit keluar secara bersamaan pada bulan April-Mei 2005 pada saat suhu air laut meningkat (Riesgoa \& Maldonado 2008), sementara di White Sea gametogenesis Halichondria panacea berlangsung pada bulan Juni dan Halichondria sitiens berlangsung dari pertengan Juni sampai pertengahan (Gerasimova \& Ereskovsky 2007). Beberapa penelitian juga memperlihatkan bahwa gametogenesis tidak berhubungan sama sekali dengan suhu. Faktor lain yang mungkin penting adalah cahaya, khususnya fotoperiode dan ketersediaan makanan (Sara 1992).

Di daerah tropik, walaupun studi reproduksi sponge masih relatif sedikit, tetapi beberapa penelitian sudah dapat memberikan gambaran, seperti yang dilakukan oleh Ilan dan Loya (1988) yang menemukan bahwa kelihatannya gametogenesis berhubungan juga dengan peningkatan suhu perairan pada sponge Niphates sp, tetapi dijelaskan bahwa aktifitas reproduksi di atas musim kemarau dapat juga berhubungan pada musim tidak kelihatannya alga bentik. Hoppe dan Reichert (1987) menjelaskan juga bahwa pengeluaran gamet sponge jenis Neofibularia nolitangere pada daerah tropik berhubungan erat dengan fase bulan.

Untuk mengetahui karakter reproduksi sponge di daerah tropis, khususnya jenis Aaptos aaptos perlu dilakukan penelitian, terutama yang berkaitan dengan karakter perkembangan gametnya. Penelitian ini dilaksanakan di perairan tropik Pulau Barrang Lompo, Kepulauan Spermonde, Sulawesi Selatan. Penelitian diharapkan dapat dijadikan bahan informasi untuk pengembangan budidayanya di masa yang akan datang, khususnya perbenihannya.

\section{BAHAN DAN METODE}

Waktu dan Tempat. Penelitian ini berlangsung selama kurang lebih 7 bulan mulai dari Juni 2003 sampai Januari 2004. Pengambilan sampel sponge dilakukan di bagian tenggara Pulau Barrang Lompo Kepulauan Spermonde, Sulawesi Selatan. Pengamatan perkembangan gamet dilakukan di Laboratorium Ekotoksikologi dan Fisiologi Biota Laut, Fakultas Ilmu Kelautan dan Perikanan Universitas Hasanuddin Makassar. 
Prosedur Penelitian. Untuk mengetahui perkembangan gamet sponge Aaptos aaptos, dilakukan dengan cara mengambil tiga sampel jaringan sponge pada setiap fase bulan Qomariah (bulan baru, bulan seperempat, bulan purnama, dan bulan tigaperempat). Setelah diambil, spesimen dimasukkan ke dalam tissue cassette kemudian dibuat preparat histologiknya menurut metode Fromont (1999). Prosedur metode tersebut yaitu spesimen dimasukkan ke dalam larutan fiksatif FAACC (untuk $100 \mathrm{~mL}$ $=10 \mathrm{~mL}$ larutan formaldehida 37-40\%: $5 \mathrm{~mL}$ asam aseta glasial: $1.3 \mathrm{~g}$ kalsium klorida dihidrat: $85 \mathrm{~mL}$ akuades) selama \pm 48 jam, dan kemudian dipindahkan ke alkohol $70 \%$ untuk sementara waktu sebelum dilakukan pembuatan preparat histologik yang mengikuti prosedur standar. Setelah proses tersebut, selanjutnya dilakukan pengamatan histologik terhadap kehadiran dan perkembangan gamet, kemudian setelah itu dilakukan mikrofotografi menggunakan mikroskop yang dilengkapi kamera.

Analisis Data. Tingkat perkembangan gamet didasarkan pada keberadaan dan perkembangan gamet (oosit dan spermatosit) pada sampel histologik pada setiap fase bulan tahun Qamariah, yaitu pada fase bulan mati, bulan seperempat, bulan purnama, dan bulan tigaperempat. Perkembangan gamet dianalisis secara deskriptif dengan cara mengamati karakter jaringan gamet secara histologik pada preparat dan gambar hasil fotomikrografi

\section{HASIL DAN PEMBAHASAN}

Seksualitas. Sponge tidak memiliki ciri-ciri seksual sekunder yang dapat digunakan untuk membedakan seksualitasnya. Penentuan seksualitasnya hanya dapat dilakukan melalui pembedahan secara histologis. Berdasarkan studi histologis pada penelitian ini, seksualitas sponge Aaptos aaptos yang hidup di perairan Pulau Barrang Lompo adalah bertipe gonokhorik, karena di dalam satu sampel histologi tidak pernah ditemukan secara bersamasama gamet jantan dan gamet betina. Seksualitas bertipe gonokhorik pada sponge Aaptos aaptos yang hidup di Pulau Barrang Lompo juga ditemukan oleh Sara (1992) di perairan Italia dan Ayling (1980) di Lautan Pasifik, Selandia Baru. Kepastian seksualitas bertipe gonokhorik untuk jenis ini juga dipertegas dengan pengamatan secara langsung di alam pada saat beberapa sponge ini mengeluarkan gametnya secara bersama-sama pada tanggal 23 Juni 2003 jam 16.30 WIT. Gamet yang dikeluarkan secara tiba-tiba menyerupai asap rokok atau awan susu, yang keluar secara terus menerus selama sekitar 5 menit. Tipe seksualitas gonokhorik yang didapatkan pada sponge jenis Aaptos aaptos di Pulau Barrang Lompo adalah tipe seksualitas yang umum didapatkan pada sponge Ordo Hadromerida, seperti yang didapatkan juga pada jenis Tethya crypta, Tethya auratum, Tethya citrina (Tethydae); Chondrosia reniformis, Chondrilla nucula (Chondrosiidae); Polymastia hirsuta (Polymastiidae) (Sara 1992). Hasil penelitian yang dilakukan oleh Kawaroe (2009) di Pulau Pari, Kepulauan Seribu juga mendapatkan tipe seksualitas sponge Aaptos aaptos yang juga gonokhorik.

Perkembangan Gamet Jantan. Pada sponge Demospongiae perkembangan sel-sel sperma meliputi: 1) differensiasi sel-sel batang, spermatogonia; 2) pembentukan kantong sperma (spermatic cyst); dan perkembangan sperma matang. Sponge dewasa tidak mempunyai organ yang dapat diidentifikasi secara struktur sebagai organ reproduksi, dan perkembangan gamet-gamet jantan adalah differensiasi cadangan sel-sel sponge dewasa ke dalam bentuk spermatogonia, yang kemudian membentuk kantong sperma (spermatic cyst). Selama masa reproduktif, kelompokkelompok sel-sel spermatogonia terbentuk di dalam mesohyl.

Spermatogonia pada sponge umumnya berasal dari sel-sel choanocytes atau archaeocytes. Spermatogonia berkembang secara langsung dari choanocytes secara in situ, tidak mengalami mitosis tetapi diproses secara langsung untuk membentuk sperma. Perubahan choanocytes ke spermatogonia menyebabkan hilangnya collar, menekan sitoplasma dan phagosomes di bagian dasar sel, dan sel bermigrasi ke lumen yang berada di dalam chamber (Sara 1992), kemudian spermatogonia tersebut mengalami pembelahan meiosis. Kelompok spermatogonia tersebut selanjutnya dikelilingi oleh sebuah dinding selluler membentuk sebuah kantong sperma (Ruppert \& Barnes 1991) yang berasal dari sel-sel mesohyl Sara (1992). Menurut Harrison dan De Vos (1991) dan Harris (1988) spermatogenesis pada sponge terjadi di dalam kantong sperma (spermatic cyste).

Di dalam kantong sperma, spermatosit mengalami differensiasi. Menurut Harrison dan De Vos (1991) differensiasi sperma terbagi atas tiga bentuk, yaitu: 1) semua sel-sel pada semua kantong sperma (spermatic cyst) mungkin berkembang secara bersama-sama; 2) sel berdiferensiasi di dalam sebuah kantong sperma berkembang secara bersama-sama, tetapi tahap perkembangan bervariasi pada kantong sperma yang berbeda; dan 3) perkembangan 
sel di dalam beberapa kantong sperma berbeda tahap perkembangannya.

Bentuk diferensiasi sel pada sponge Aaptos aaptos adalah perkembangan sel di dalam beberapa kantong sperma berbeda tahap perkembangannya. Bentuk differensiasi sel di dalam kantong sperma pada sponge Aaptos aaptos berbeda dengan sponge yang masih satu ordo dengannya, yaitu Suberitas massa yang bentuk differensiasi selnya di dalam satu kantong sperma berbeda tahap perkembangannya (Harrison \& De Vos 1991).

Kantong sperma sponge Aaptos aaptos yang selnya (sel sperma) sudah tahap matang umumnya berbentuk lonjong. Bentuk kantong sperma sponge Aaptos aaptos ini relatif sama dengan bentuk kantong sperma sponge jenis Suberitas massa (Harrison \& De Vos 1991), Mycale sp (Fromont 1999), Ircinia strobilina (Hoppe 1988), tetapi berbeda dengan sponge jenis Xestospongia testudinaria (Fromont 1988), Xestospongia exigua (Fromont \& Bergquist 1994), Niphates nitida (Fromont 1994), Petrosia sp (Asa et al. 2000) yang bentuknya tidak beraturan, sedangkan jenis Halichondria panacea dan Halichondria sitiens bentuknya bulat (Gerasimova \& Ereskovsky 2007).

Secara histologis, pada tahap spermatosit I, spermatosit di dalam kantong sperma belum terlihat dengan jelas, jaringan ikat terlihat terlihat lebih dominan, warna kantong sperma dan spermatositnya merah muda keputihputihan, dan ukuran kantong sperma masih relatif kecil, diameternya berkisar 24-41 mm.

Pada tahap spermatosit II, spermatosit di dalam kantong sperma sudah agak kelihatan batas-batasnya, warna kantong sperma dan spermatositnya tetap warna merah mudah yang agak tua keputih-putihan, ukuran kantong sperma lebih besar daripada di spermatosit II, diameternya berkisar 42-54 mm.

Pada tahap spermatosit III, spermatosit di dalam kantong sperma jelas kelihatan batas-batasnya, di beberapa tempat inti spermatosit kelihatan berwarna biru kehitamhitaman, ukuran kantong sperma lebih besar daripada di spermatosit II, diameternya berkisar 55-66 mm. Jika dibandingkan dengan sponge jenis Axinella damicornis ukuran kantong tersebut jauh lebih kecil. Hasil penelitian Riesgo dan Maldonado (2008) mendapatkan ukuran kantong sperma (spermatosit matang) sponge jenis Axinella damicornis $\leq 200 \mathrm{~mm}$ dan jenis Raspaciona aculeate $200 \mathrm{~mm}$.

Pada tahap IV (spermatid), spermatosit sudah berubah menjadi spermatid. Bila dilakukan pembesaran gambar beberapa kali (zoom) nampak dengan jelas spermatid sudah memiliki kepala dan ekor, ukuran sitoplasma spermatid semakin kecil, pada saat ini spermatid sudah hampir membentuk sperma. Ukuran kantong sperma pada tahap ini lebih besar daripada di spermatosit III dan hampir mencapai maksimum, diameternya berkisar 67-90 mm (Gambar 1).

Perkembangan Gamet Betina. Seperti pada sponge jantan, oogonia pada sponge betina juga berasal dari choanocytes atau archaeocytes (Harris 1988; Ruppert \& Barnes 1991; Harrison \& De Vos 1992). Oosit umumnya mengakumulasi cadangan nutrisinya melalui penelanan sel-sel perawat (nurse cells) yang berada didekatnya dan biasanya terdapat di dalam suatu kelompok sel-sel yang mengelilinginya (Ruppert \& Barnes 1991)

Sel-sel khusus yang bertindak sebagai sel-sel perawat (nurse cells) pada sponge sangat bervariasi, seperti:

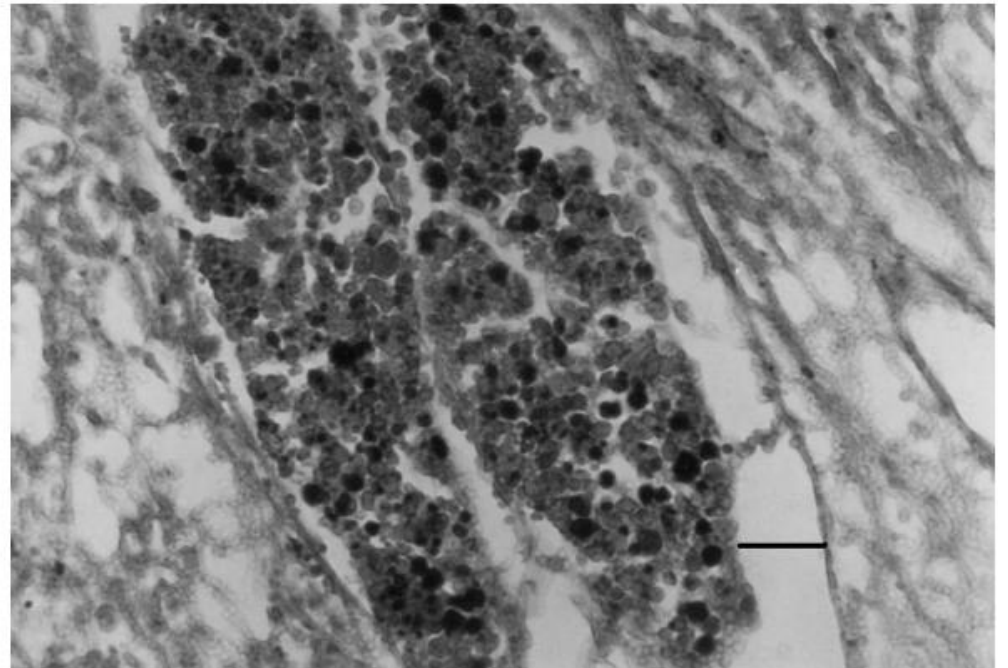

Gambar 1 Spermatosit tahap IV (spermatid) di dalam kantong sperma (spermatic cyst) pada sponge laut Aaptos aaptos 
archaecyte, sel-sel spherulous, sel-sel microgranular, sel-sel hijau, sel-sel eosinophilic, sel-sel seperti oocytes, follicular ephithelium, dan chonocyte. Selain dari sel-sel perawat (nurse cells), mekanisme lain yang dipakai oleh sebagian sponge untuk mendapatkan nutrisi oositnya adalah melalui diabsorbsi oleh pinasitosis, fagositosis oleh pseudopodia yang bersentuhan dengan bermacam-macam tipe sel, tetapi pada umumnya diabsorbsi secara pinasitosis (Harrison \& De Vos 1992).

Secara histologis, pada tahap oosit I, oosit ukurannya masih sangat kecil, inti sel belum nampak jelas, begitu pula anak inti. Ukuran oosit pada tahap ini adalah berkisar 20-45 mm. Pada tahap ini oosit menyebar dalam kelompokkelompok kecil pada lapisan mesohyl, sedangkan hasil penelitian Ramili (2007), karakter oosit I yang dia dapatkan adalah dinding oosit belum terlihat jelas dan batas antara oosit belum jelas. Ukuran oosit sekitar $10 \mathrm{~mm}$, inti dan anak inti belum terlihat. Pada pengamatan melalui Scanning Electron Microscope (SEM) yang dilakukan oleh Harrison dan De Vos (1992) terhadap sponge jenis Ephydatia fluviatilis, pada tahap ini oosit sebenarnya sudah mempunyai sebuah nukleus ditengahnya yang dikelilingi oleh sitoplasma yang permukaannya luas.

Pada tahap oosit II, oosit semakin besar dan ukurannya lebih besar daripada oosit I. Ukuran oosit pada tahap ini adalah berkisar 48-66 mm. Pada tahap ini inti sudah agak kelihatan, butiran-butiran lemak pada sitolasma sudah mulai kelihatan. Penelitian Ramili (2007), karakter oosit II yang dia dapatkan adalah dinding oosit sudah terbentuk dan cukup tebal, sehingga batas antara oosit terlihat jelas. Ukuran oosit II sekitar $25 \mathrm{~mm}$, dengan inti yang sudah kelihatan, dan butiran lemak mengelilingi inti. Menurut Fromont (1988) pada jenis Xestospongia testudinaria, pada tahap awal oosit berukuran kecil dengan inti yang kelihatan dan berukuran 7 mm diameternya. Oosit berisi butiran-butiran kuning telur dekat pinggiran bagian luarnya. Pinggiran bagian luar oosit tidak selalu dibatasi oleh sebuah lapisan epitel, dan beberapa pertukaran selluler kelihatan terjadi antara oosit dengan jaringan induknya. Sel-sel kecil yang diamati dengan teliti berhubungan dengan perkembangan oosit tetapi tidak dapat dijadikan ciri-ciri secara morfologi yang terjadi pada sel-sel sponge dewasa secara keseluruhan.

Pada tahap oosit III, oosit sudah semakin besar dan ukurannya lebih besar daripada oosit II. Ukuran oosit pada tahap ini adalah berkisar 67-83 mm. Pada tahap ini butiranbutiran lemak sudah semakin memadat, sedangkan karakter oosit III yang didapatkan oleh Ramili (2007) adalah berbentuk agak berlekuk, ukuran oosit sekitar $50 \mathrm{~mm}$, butiran-butiran lemak mulai memadat, dan inti semakin besar dan berwarna agak gelap. Menurut Hoppe (1988) pada tahap ini, untuk jenis Ircinia strobilina oositnya dikelilingi oleh sel-sel follikel, dan intinya sudah bergeser dari tengah ke arah pinggir.

Pada tahap oosit IV (matang), oosit sudah semakin besar dan mencapai ukuran maksimum. Pada tahap ini oosit sudah berubah menjadi ootid atau telur yang siap dipijahkan. Ukurannya pada tahap ini lebih besar daripada oosit III. Ukuran ootid atau telur pada tahap ini adalah berkisar 84-134 mm. Pada tahap ini butiran-butiran lemak sudah semakin memadat, oosit membentuk kelompok dalam sebuah untaian yang dilekatkan antara satu oosit dengan oosit lainnya oleh semacam lendir (Gambar 2), sedangkan menurut

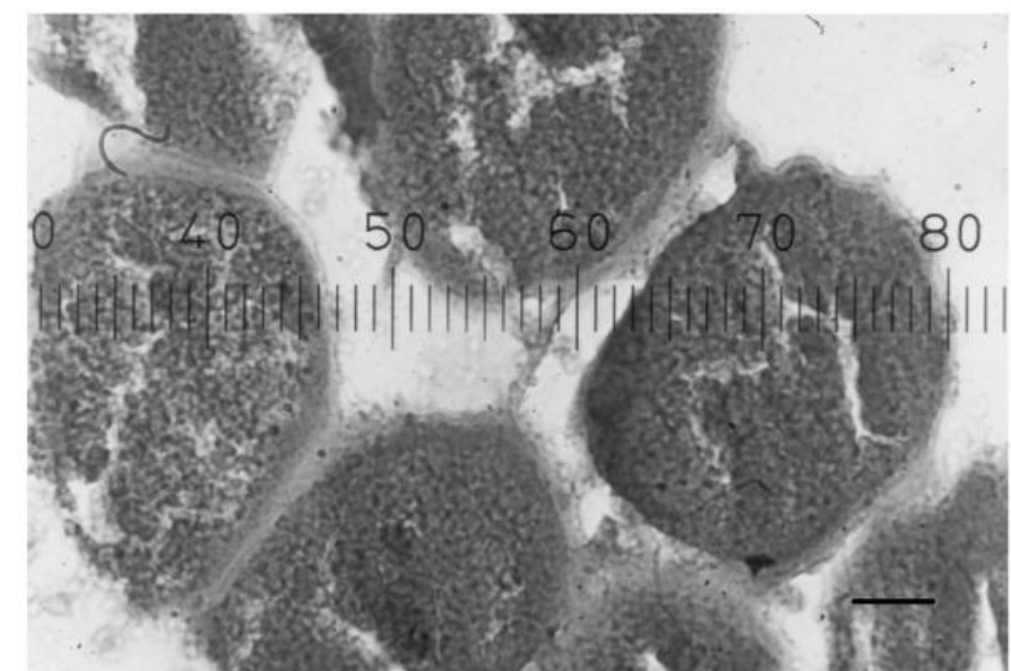

Gambar 2 Oosit tahap IV (matang) pada sponge laut Aaptos aaptos 
Ramili (2007), karakter oosit IV adalah ukuran semakin membesar akibat akumulasi kuning telur, bentuknya agak membulat, ukuran oosit sekitar $65 \mathrm{~mm}$, butiran-butiran lemak sudah semakin memadat, dan inti dan anak inti bergeser ke pinggir. Hasil penelitian Riesgo dan Maldonado (2008) mendapatkan ukuran diameter oosit tahap matang sponge jenis Corticium candelabrum 125-150 mm dan Raspaciona aculeate $160-180 \mathrm{~mm}$

Pada tahap matang, ootid tumbuh secara terus menerus dan menjadi sebuah sel yang sangat besar. Pertumbuhan ini diikuti oleh suatu akumulasi sejumlah besar cadangan kuning telur yang disediakan secara parsial oleh sel-sel perawat (nurse cells) (Harrison \& De Vos 1991). Pada jenis Xestospongia testudinaria, inti telur sudah berada di bagian pinggir (Fromont 1988). Selama pematangan oosit, trophocytes dan sel-sel follikel membentuk suatu pembungkus follikular. Ketebalan dan banyaknya pelapisan dimulai pada pembungkus follikular, lapisan ini tumbuh lebih tebal secara progresif, mengelilingi oosit. Sitoplasma oosit secara bertahap dipenuhi dengan partikel-partikel kuning telur. Pada akhir pembentukan oosit, sitoplasma menyempurnakan pengambil cadangan kuning telurnya (Harrison \& De Vos 1992).

\section{SIMPULAN}

Seksualitas yang hidup di perairan Pulau Barrang Lompo bertipe gonokhorik, yaitu: sponge yang memproduksi hanya gamet jantan atau betina selama hidupnya, kantong sperma sponge Aaptos aaptos berbentuk lonjong, dan Perkembangan gamet jantan dan gamet betina pada sponge Aaptos aaptos terbagi atas empat tahap, yaitu: tahap I, II, III, dan IV dengan karakter gamet yang berbeda-beda antara tahap yang satu dengan tahap yang lainnya.

\section{UCAPAN TERIMA KASIH}

Pada kesempatan ini penulis menyampaikan ucapan terima kasih kepada saudara Iswan Ali, Haikal Amirullah, dan saudari Ristawati Alwi yang telah membantu kami di lapangan dan di laboratorium. Ucapan yang sama kami sampaikan kepada Kepala dan laboran Laboratorium Fisiologi Hewan Air Fakultas Ilmu Kelautan dan Perikanan Unhas yang telah memfasilitasi kami membuat sediaan histologi.

\section{DAFTAR PUSTAKA}

Amir, I \& Budiyanto, A. 1996. Mengenal sponge laut (Demospongiae) secara umum. Oseana XXI(2): 15-31.

Asa, S., Yeemin, T., Chaitanawisuti, N \& Kritsanapuntu, A. 2000. Sexual Reproduction of a Marine Sponge, Petrosia sp from Coral Communities in the Gulf of Thailand. Proceedings $9^{\text {th }}$ International Coral Reef Symposyum, Bali, Indonesia 23-27 October 2000 1: 421-424.

Ayling, A.L. 1980. Patterns of sexuality, asexual reproduction and recruitment in some subtidal marine demospongiae. Biol Bull 158: 271-282.

Bergquist, P.R. 1978. Sponges. London: Hutchinson.

Bergquist, P.R \& Fromont P.J. 1988. The marine fauna of New Zealand: porifera, demospongiae, part 4 (poecilosclerida). New Zealand department of Scientific and Industrial Research. New Zealand Oceanographic Institute Memoirs No. 96: 7-197.

Brusca, R.C \& Brusca, G.J. 1990. Invertebrates. sinauer associates, inc. publishers. Sunderland, Massachusetts.

Ereskovsky, A.V \& Gonobobleva, E.L. 2000. New data on embryonic development of Halisarca dujardini Johnston, 1842 (Demospongiae, Halisarcida). Zoosystema 22: 355-368.

Fromont, J. 1994. Reproductive development and timing of tropical sponges (order haplosclerida) from the great barrier reef, Australia. Coral Reef 13: 127-133.

Fromont, J. 1988. Aspects of the reproductive biology of xestospongia testudinaria (Great Barrier Reef). Proceedings of the $6^{\text {th }}$ International Coral Reef Symposium, Australia 1988, 2: 685-691.

Fromont, J. 1999. Reproduction of some demosponges in a temperate australian shallow water habitat. Memoir of the Queensland Museum 44: 185-192.

Fromont, J \& Bergquist, P.R. 1994. Reproductive biology of three sponge species of the genus xestospongia (porifera: demospongiae: petrosida) from the great barrier reef. Coral Reef 13: 119-126.

Harris, V.A. 1988. Sessile Animals of the Sea Shore. Chapman and Hall. London.

Harrison, F.W \& De Vos L. 1991. Porifera. Di dalam: Harrison FW, Westfall JA (ed.). Microscopic Anatomy of Invertebrates. Volume 2. Placozoa, Porifera, Cnidaria, and Ctenophora. Wiley-Liss. A John Wiley \& Sons, Inc., Publication. New York

Hoppe, W.F. 1988. Growth, regeneration and predation in three species of coral reef sponges. Mar.Ecol.Prog.Ser 50: $117-125$.

Hoppe, W.F \& Reichert, M.J.M. 1987. Predictible annual mass release of gametes by the coral reef sponge neofibularia nolitangere (Porifera), Demospongiae). Mar Biol 94: 277-286.

Ilan, M. \& Loya Y. 1988. Reproduction and Settlement of the Coral Reef Sponge Niphates sp (Red Sea). Proceedings 
of the $6^{\text {th }}$ International Coral Reef Symposium, Australia, 1988, Vol.2: 745-749.

Kawaroe, M. 2009. Fragmentasi Buatan dan Reproduksi Seksual Spons Aaptos aaptos dalam Upaya Perbanyakan Stok Koloni Di Alam. Disertasi. Program Studi Ilmu Kelautan Program Pasca Sarjana Institut Pertanian Bogor.

Kozloff, E.N. 1990. Invertebrates. Saunders College Publishing.

Mercurio, M., Corriero, G. \& Gaino, E. 2007. A3-year investigation of sexual reproduction in Geodia cydonium (Jameson 1811) (Porifera, Demospongiae) from a semienclosed Mediterranean bay.Mar. Biol 151: 1491-1500.

Ramili, Y. 2007. Struktur morfologis dan perkembangan gonad spons Aaptos aaptos (Schmidt 1864) (Kelas
Demospongiae) di Perairan Pulau Pari, Kepulauan Seribu, DKI Jakarta. Tesis. Sekolah Pascasarjana Institut Pertanian Bogor.

Reseck, J. Jr. 1988. Marine Biology. Second Edition. A Reston Book. Prentice Hall, Englewood Cliff, N.J. 07632.

Ruppert, E.E \& Barnes R.D. 1991. Invertebrates zoology. sixth edition. Saunders College Publishing. Philadelphia.

Sara, M. 1992. Porifera. Di dalam: Adiyodi KG, Adiyodi RG (Ed.). Reproductive Biology of Invertebrates. Volume V. Sexual Differentiation and Behaviour. John Wiley \& Sons, New York.

Riesgo, A \& Maldonado, M. 2008. Differences in reproductive timing among sponges sharing habitat and thermal regime. Invertebrate Biology 127(4): 357-367. 